MJCCA9 - 580

Received: May 28, 2011

Accepted: July 14, 2011

\title{
DISSOLVED INORGANIC ANTIMONY, SELENIUM AND TIN SPECIES IN WATER SAMPLES FROM VARIOUS SAMPLING SITES OF RIVER VARDAR IN MACEDONIA AND GREECE
}

\author{
Jožica Majda Serafimovska1, Sonja Arpadjan², Trajče Stafilov ${ }^{*}$, \\ Stanko Ilik Popov ${ }^{1}$
}

${ }^{1}$ Institute of Chemistry, Faculty of Natural Sciences and Mathematics, Ss. Cyril and Methodius University, P.O. Box 162, 1000 Skopje, R. Macedonia

${ }^{2}$ Faculty of Chemistry, University of Sofia "St. Kl. Ohridsky", 1164 Sofia, J. Bourchier blvd. 1, Bulgaria

*e-mail: trajcest@pmf.ukim.mk

\begin{abstract}
A highly effective liquid phase semi-microextraction procedure was applied for determination of ultra trace levels of dissolved inorganic species of antimony, tin and selenium in river Vardar (from the 2nd up to 420th km of the river) and its tributaries Crna Reka, Treska, Bregalnica, Pchinja and Lepenec using electrothermal atomic absorption spectrometry (ETAAS) for quantification. The concentrations for total dissolved inorganic antimony were between 6 and $242 \mathrm{ng} / 1 \mathrm{Sb}$, for Sn(II, IV) - in the range of 2.7-61 ng/l $\mathrm{Sn}$ and for Se(IV, VI) - in the range of 15-75 ng/l Se. The higher oxidation states of antimony and selenium were found as the predominant form in the studied surface waters.
\end{abstract} metry

Keywords: speciation; antimony; selenium, tin; water; electrothermal atomic absorption spectro-

\author{
РАСТВОРЕНИ НЕОРГАНСКИ ФОРМИ НА АНТИМОН, СЕЛЕН И КАЛАЈ \\ ВО ПРИМЕРОЦИ ВОДА ОД РАЗЛИЧНИ МЕРНИ МЕСТА НА РЕКАТА ВАРДАР \\ ВО МАКЕДОНИЈА И ГРЦИЈА
}

\begin{abstract}
Применета е високо осетлива течно-фазна семимикроекстракција за определување ултратраги од растворените неоргански хемиски форми на антимон, калај и селен во водите од реката Вардар (од вториот до 420-ти km на реката) и нејзините притоки Црна Река, Треска, Брегалница, Пчиња и Лепенец и нивно квантифицирање со електротермичка атомска апсорпциона спектрометрија (ETAAC). Концентрациите на вкупниот растворен антимон се движат од 6 до $242 \mathrm{ng} / \mathrm{l} \mathrm{Sb}$, за $\mathrm{Sn}(\mathrm{II}, \mathrm{IV})$ во областа од 2,7 до $61 \mathrm{ng} / \mathrm{l} \mathrm{Sn}$ и за $\mathrm{Se}(\mathrm{IV}, \mathrm{VI})$ од 15 до $75 \mathrm{ng} / \mathrm{l} \mathrm{Se.} \mathrm{Утврдено} \mathrm{е} \mathrm{дека} \mathrm{во}$ испитуваните примероци од површинските води повисоките оксидациони форми на антимон и селен се доминантни хемиски форми.
\end{abstract}

Клучни зборови: специјација; антимон; селен; калај; вода; електротермичка атомска апсорпциона спектрометрија 


\section{INTRODUCTION}

Speciation of trace metals involves the determination of the chemical forms of the metal. This includes the evaluation of free metal ions, inorganic and organic complexes and organometallic compounds. Because the bioavailability of metals depends on chemical form or speciation it is necessary that analytical methods are available to determine or predict the bioavailable fraction of a metal. Biological effects have most commonly been related to the free metal ion activity.

Antimony and selenium were considered as pollutants of priority interest. The European Union established maximum allowed concentrations of $5 \mu \mathrm{g} / \mathrm{l} \mathrm{Sb}$ and of $10 \mu \mathrm{g} / \mathrm{l} \mathrm{Se}$ in drinking and surface waters [1-3]. In view of its low toxicity, the presence of tin in drinking and surface waters does not represent a hazard to human health. For this reason, inorganic tin is not included in the European list of water pollutants [4]. The permissible concentration of inorganic tin in surface waters according to Macedonian national regulations is $100 \mu \mathrm{g} / \mathrm{l} \mathrm{Sn}$ for first and second class and $500 \mu \mathrm{g} / 1 \mathrm{Sn}$ for third class surface waters [5].

In the environment antimony is present in forms of $\mathrm{Sb}(\mathrm{III}), \mathrm{Sb}(\mathrm{V})$ and methyl derivatives: monomethyloantimonic and dimethyloantimonic acid. Selenium occurs in the environment as $\mathrm{Se}(\mathrm{IV}), \mathrm{Se}(\mathrm{VI})$, di- and trimethyloselenium, selenoaminoacids (selenocystein, selenometionin), and in many organic compounds. Tin occurs as $\mathrm{Sn}(\mathrm{II}), \mathrm{Sn}(\mathrm{IV})$, butyl-, phenyltin and a lot of other organic tin compounds. The inorganic species of $\mathrm{Sb}$ and $\mathrm{Se}$ are more toxic than their organic forms. In contrary, tributyltin is considered as one of the most toxic tin containing substances $[6,7]$.

The concentrations of $\mathrm{Sb}$, Se and $\mathrm{Sn}$ in nonpolluted waters are less than $1 \mu \mathrm{g} / \mathrm{l}$. It requires application of highly sensitive hyphenated analytical procedures for accurate and reliable speciation analysis. The developed in our laboratory highly effective liquid-liquid semimicroextraction procedure for determination of $\mathrm{Sb}(\mathrm{III})$ and $\mathrm{Sb}(\mathrm{V})$ in waters [8] can be success- fully applied for determination of $\mathrm{Se}(\mathrm{IV}), \mathrm{Se}(\mathrm{VI})$ and total $\mathrm{Sn}(\mathrm{II})+\mathrm{Sn}(\mathrm{IV})$.

The present paper shows the results of determination of total concentration and the results of speciation analysis of antimony, selenium and tin in water from 34 sampling points of river Vardar (V) and its tributaries: Crna Reka (CR), Treska (TR), Bregalnica (BR), Pchinja (PC) and Lepenec (LE). Vardar is the longest and major river of Macedonia and also major river of Greece. Lead, cadmium, zinc and chromium(VI) were analyzed in samples of river Vardar [9]. But there are no data about the content of $\mathrm{Sb}, \mathrm{Se}$ and $\mathrm{Sn}$ in Vardar river and its tributaries. The aim of this research was to investigate the distribution of these elements from $2 \mathrm{~km}(\mathrm{~V}-1)$ up to $420 \mathrm{~km}$ $(\mathrm{V}-18)$ of the river to estimate the anthropological factors on the species distribution, species mobility, accumulation, transformation, to elucidate the processes in which elements take part in the environment.

\section{EXPERIMENTAL}

\subsection{Instrumentation}

The electrothermal atomic absorption spectrometry (ETAAS) measurements were carried out using a Perkin-Elmer (Norwalk, CT, USA) Zeeman 3030 spectrometer with an HGA-600 graphite furnace. The light sources were electrodeless discharge lamps for $\mathrm{Sb}$, Se and $\mathrm{Sn}$. The selected wavelengths were $217.6 \mathrm{~nm}$ for Sb, $196.0 \mathrm{~nm}$ for Se and $233.5 \mathrm{~nm}$ for Sn. The spectral bandpass was $0.2 \mathrm{~nm}$ for $\mathrm{Sb}$, Sn and $0.7 \mathrm{~nm}$ for Se. Standard uncoated graphite tubes were used as atomizer. The injection of $20 \mu \mathrm{l}$ organic phase was performed manually. Only peak areas were used for quantification. The graphite furnace operating parameters for ETAAS measurements are presented in Table 1. The extractant ammonium pyrrolidine dithiocarbamate (APDC) used for preconcentration/speciation of $\mathrm{Sb}$ acts as a matrix modifier for the determination of this element [10]. Palladium (5 $\mu \mathrm{l} 1000 \mathrm{ppm} \mathrm{Pd}$ ) was used as matrix modifier for ETAAS determination of Se and Sn. 
$\mathrm{T}$ a b 1 e 1

Electrothermal atomization programme for determination of antimony, selenium and tin as dithiocarbamate complexes in xylene by ETAAS with Zeeman background correction Modifier for Se and $\mathrm{Sn}-5 \mu 1000 \mathrm{ppm} \mathrm{Pd}$

\begin{tabular}{|c|c|c|c|c|}
\hline \multirow{3}{*}{ Step } & \multicolumn{3}{|c|}{ Temperature } & \multirow{3}{*}{$\begin{array}{c}\text { Internal gas (Ar) flow rate } \\
\mathrm{ml} / \mathrm{min}\end{array}$} \\
\hline & \multicolumn{3}{|c|}{${ }^{\circ} \mathrm{C}(\mathrm{a}, \mathrm{b})$} & \\
\hline & $\mathrm{Sb}$ & $\mathrm{Se}$ & $\mathrm{Sn}$ & \\
\hline Drying & $120(10,10)$ & $120(10,10)$ & $120(10,10)$ & 300 \\
\hline Pretreatment & $1100(10,10)$ & $1200(12,10)$ & $1400(15,10)$ & 300 \\
\hline Atomization & $1700(0,3)$ & $2200(0,3)$ & $2300(0,3)$ & 0 \\
\hline Cleaning & $2300(2,3)$ & $2500(0,3)$ & $2500(0,3)$ & 300 \\
\hline
\end{tabular}

$\mathrm{a}$ - ramp time; $\mathrm{b}$ - hold time

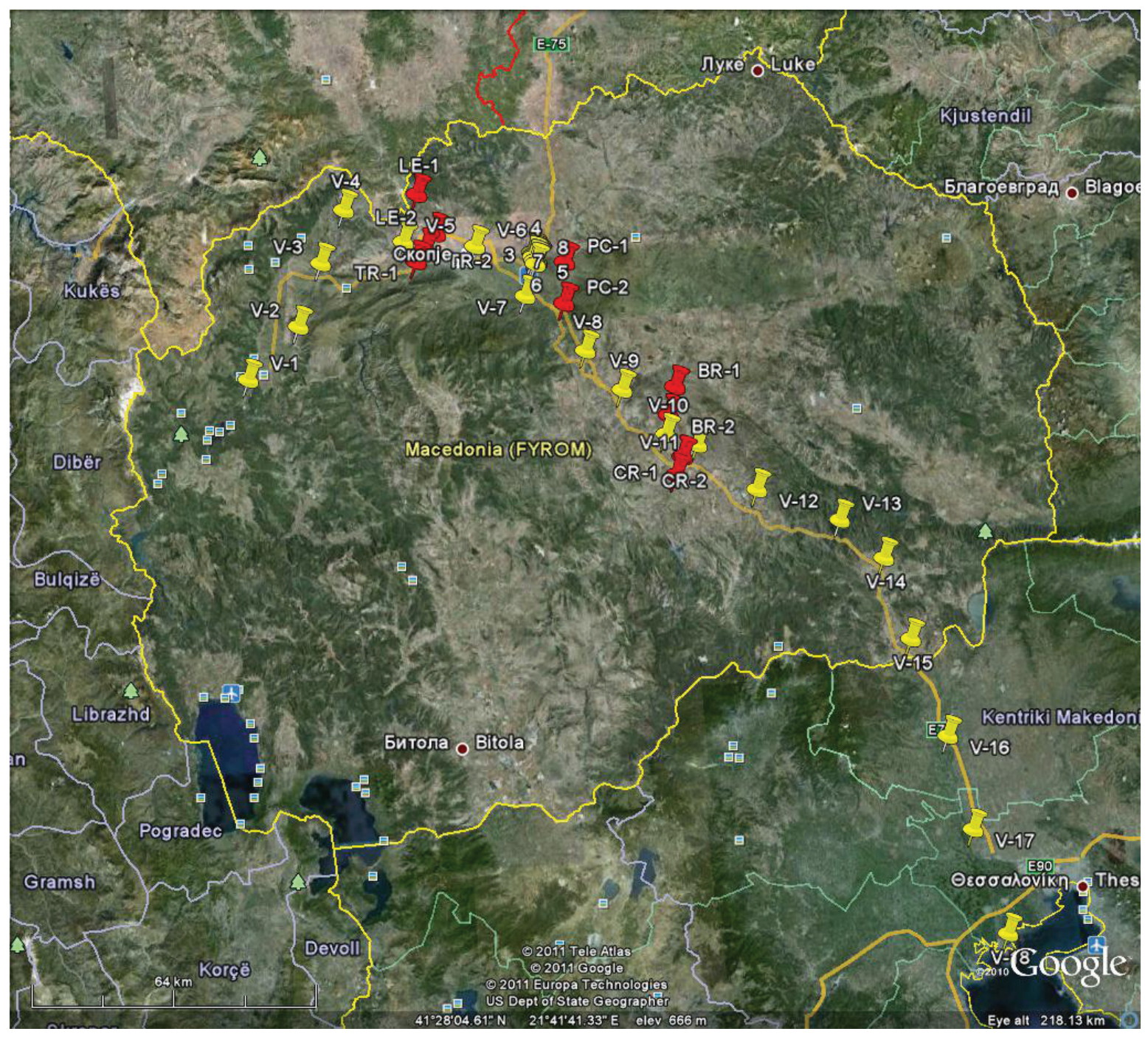

Fig. 1. Sampling sites 


\subsection{Reagents and materials}

All reagents used were of analytical reagent grade. Doubly distilled water was used throughout the study. A ready for use stock standard solutions for AAS (Merck, Darmstadt, Germany) with concentration of $1 \mathrm{~g} / \mathrm{l} \mathrm{Sb}$ (III), $\mathrm{Se}(\mathrm{IV})$ and $\mathrm{Sn}(\mathrm{IV})$ were used. Intermediate standard solutions with concentration $10 \mu \mathrm{g}$ $\mathrm{ml}^{-1}$ were prepared weekly by appropriate dilution with $0.5 \mathrm{~mol} / 1 \mathrm{HCl}$. The standard solutions at $\mathrm{ng} / \mathrm{mL}$ level were prepared daily.

River water reference material for trace metals SLRS-5 (National Research Council Canada) with information value for antimony of $0.3 \mu \mathrm{g} / 1$ was used after fivefold dilution for checking the accuracy of the developed method.

\subsection{Sample collection and preparation}

The samples were collected in high density polyethylene (PE) bottles and filtered through $0.45 \mu \mathrm{m}$ membrane filters. Then to the filtrates solid EDTA ( $1 \mathrm{~g} / 1$ EDTA) was added and mixed. The filtrates were transferred to

T a b l e 2

Characteristic parameters of water samples from river Vardar

\begin{tabular}{lcc}
\hline \hline Parameter & $\begin{array}{c}\text { Minimum } \\
\text { value }\end{array}$ & $\begin{array}{c}\text { Maximum } \\
\text { value }\end{array}$ \\
\hline $\mathrm{pH}$ & 7.40 & 8.45 \\
Dissolved oxygen (mg/l) & 10.6 & 12.3 \\
$\begin{array}{l}\text { Hydrogen carbonates } \\
(\mathrm{mg} / \mathrm{l})\end{array}$ & 85 & 156 \\
Carbonates (mg/l) & 3.4 & 8.4 \\
Chlorides (mg/l) & 10.6 & 13.2 \\
Sulphates (mg/l) & 10.1 & 27.2 \\
Calcium (mg/l) & 26 & 49 \\
Magnesium (mg/l) & 9 & 11 \\
\hline \hline
\end{tabular}

the laboratory and stored in a refrigerator at 4 ${ }^{\circ} \mathrm{C}$. The separation/preconcentration procedure was finished within 5 days of sample collection. Sampling points are presented in Figure 1. Characteristic parameters of the waters of river Vardar are summarized in Table 2.

\subsection{Procedure}

The sample was placed in a $100 \mathrm{ml}$ volumetric flask up to the mark. One milliliter conc. $\mathrm{HCl}(37 \%, m / V)$ was added and the sample was homogenized by shaking. Then 0.5 $\mathrm{ml} \mathrm{2 \%}$ ammonium pyrrolidine dithiocarbamate (APDC) and $250 \mu \mathrm{l}$ xylene were added. The extraction was performed shaking the flask for $8 \mathrm{~min}$. The organic phase remains as upper layer above the aqueous phase. Without any separation this xylene phase containing the dithiocarbamate complexes of the both $\mathrm{Sb}$ (III) and $\mathrm{Sb}(\mathrm{V}), \mathrm{Sn}$ (II) $+\mathrm{Sn}(\mathrm{IV})$ and of Se(IV) species was directly introduced into the graphite furnace and the temperature program (Table 1) was started. The obtained absorbance signals correspond to the concentration of i) total inorganic antimony + organic no charged antimony species; ii) total inorganic tin + organic no charged tin species; iii) $\mathrm{Se}(\mathrm{IV})$ + organic no charged selenium species. To a second aliquot of the sample placed in a 100 $\mathrm{ml}$ volumetric flask $1 \mathrm{ml}$ of $1 \mathrm{~mol} / \mathrm{l}$ acetate buffer solution ( $\mathrm{pH} \mathrm{5)}, 0.5 \mathrm{ml} 2 \%$ APDC and $250 \mu \mathrm{l}$ xylene were added. After $8 \mathrm{~min}$ extraction the concentration of $\mathrm{Sb}$ (III) was measured in the xylene phase by ETAAS. To a third aliquot of the sample placed in a 100.0 ml volumetric flask $250 \mu \mathrm{l}$ xylene were added. After 8 min extraction the concentration of no charged organic species of $\mathrm{Sb}, \mathrm{Sn}$ and Se were measured in the xylene phase by ETAAS. For determination of total selenium, Se(VI) species were preliminary reduced to $\mathrm{Se}(\mathrm{IV})$ with ascorbic acid $(0.5 \mathrm{~g}$ ascorbic acid dissolved in $100 \mathrm{ml}$ sample, acidified with $1 \mathrm{ml}$ conc. $\mathrm{HCl}$ ). 


\section{RESULTS AND DISCUSSION}

In our previous work a highly effective liquid phase semi-microextraction procedure was developed for 400 fold preconcentration/ speciation of inorganic antimony species in environmental waters [8]. It was established from further laboratory experiments with tap, river and lake waters that at the optimal conditions for quantitative extraction of inorganic $\mathrm{Sb}$ (III) and $\mathrm{Sb}(\mathrm{V})(\mathrm{pH} 1.0 \pm 0.2$; extraction time $8 \mathrm{~min})$ the following species of Se and Sn can be completely transferred from $100 \mathrm{ml}$ water to $250 \mu \mathrm{l}$ xylene:

- inorganic Se(IV);

- inorganic Sn(II, IV);

- organic no charged complexes of $\mathrm{Sb}, \mathrm{Se}$ and Sn.

In order to differentiate the organic from inorganic antimony, selenium and tin species, the liquid phase semi-microextraction has to be performed in absence of APDC. It could be expected that xylene as organic solvent with low polarity will extract only the nonpolar uncharged organic species of antimony, selenium and tin. The concentration of inorganic species can be calculated from the difference between the total content and the concentration of organic species. In this way the semi-microextraction procedure summarized in Figure 2 allows preconcentration/ speciation of antimony, selenium and tin species in natural waters.

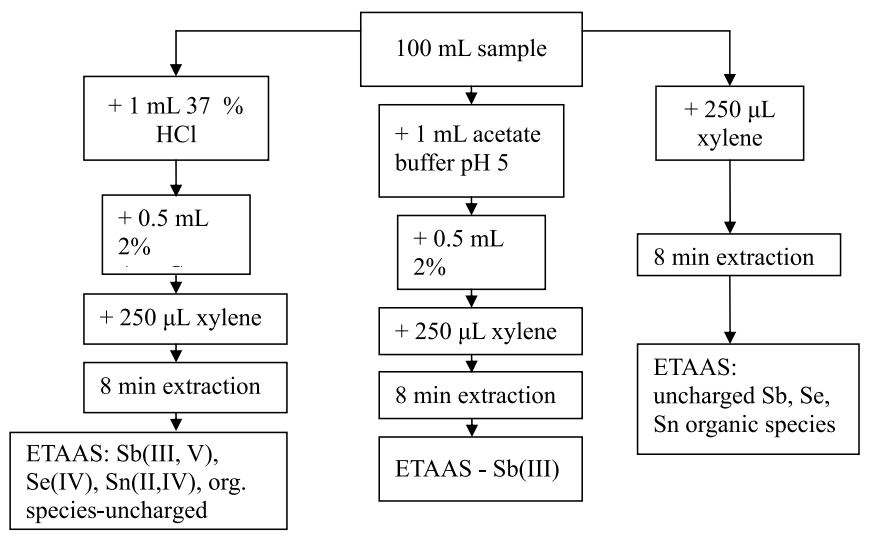

Fig. 2. Schematic presentation of liquid phase semimicroextraction for preconcentration /speciation of $\mathrm{Sb}, \mathrm{Se}$ and $\mathrm{Sn}$

\subsection{Analytical performance of procedure}

Quantification has been performed based on calibration using $0.1 \mathrm{~mol} / 1 \mathrm{HCl}$ spiked with $100 \mathrm{ng} / \mathrm{ml} \mathrm{Sb(III),} \mathrm{Se(IV),} \mathrm{Sn(IV).} \mathrm{The}$ detection limit (evaluated as the concentration corresponding to three times the standard deviation of seven replicate measurements of a blank sample) of this method with an enrichment factor of 400 was $2 \mathrm{ng} / \mathrm{l}$ of Sb Sn, and $5 \mathrm{ng} / \mathrm{l}$ of Se. The relative standard deviations for spiked samples were lower than $9 \%$. But for samples and species fractions with analyte species content around the detection limit relative standard deviations up to $25 \%$ were registered. The accuracy of $\mathrm{Sb}$ determination was routinely checked with each run using fivefold diluted certified river water reference material SLRS5 (National Water Research Institute, Canada). Recovery studies of Sn and Se were performed sequentially after spiking river water samples with these analytes. Mean recoveries were between 93 and $106 \%$ which is in the accepted range for recovery (90-110\%) [11].

\subsection{Application to analysis of samples from river Vardar}

The semi-microextraction procedure, described in Section 2.4 and presented in Figure 2 were applied for analysis of river waters from 25 sites of Vardar, Macedonia, 3 sites of Vardar, Greece (3) and 8 sites of rivers flowing into Vardar, Macedonia. The results from the analysis of the total content of inorganic $\mathrm{Sb}$, Se and Sn are presented in Table 3. The results from speciation analysis performed for six samples are given in Table 4. From the results the following conclusions can be done:

- The concentrations of $\mathrm{Sb}, \mathrm{Se}$ and $\mathrm{Sn}$ in river Vardar are far below the permissible levels.

- Inorganic antimony(V) is the predominant form.

- No charged organic antimony species were not detected. 
- Selenium(VI) is the predominant inorganic selenium form.

- No charged organic selenium species were not detected.

- No charged organic tin species were detected in only three of investigated 34 samples at concentrations $54 \mathrm{ng} / \mathrm{l}(\mathrm{V}-10), 62 \mathrm{ng} / \mathrm{l}$ (V-16) and $67 \mathrm{ng} / \mathrm{l}(\mathrm{V}-17)$.

- For antimony a trend of enhancing of its concentration from the second kilometer to $388 \mathrm{~km}$ of the river was observed. The concentrations of $\mathrm{Sb}$ in river Vardar and its tributaries become higher after the cities of Skopje (V-6) and Veles, the inflow of Bregalnica river (after $\mathrm{V}-7)$ and in the samples from Bregalnica river $(\mathrm{Br}-1$ and $\mathrm{BR}-2)$ mainly due to the anthropogenic activities [12-16].

$\mathrm{T}$ a b l e 3

Inorganic antimony, tin and selenium in river Vardar

(Number of parallel determinations $n=2-3$ )

\begin{tabular}{|c|c|c|c|}
\hline Sampling site & $\begin{array}{c}\mathrm{Sb}(\mathrm{III}, \mathrm{V}) \\
\mathrm{ng} / \mathrm{l}\end{array}$ & $\begin{array}{c}\text { Sn(II, IV) } \\
\text { ng/l }\end{array}$ & $\begin{array}{c}\mathrm{Se}(\mathrm{IV}, \mathrm{VI}) \\
\mathrm{ng} / \mathrm{l}\end{array}$ \\
\hline $\mathrm{V}-1$ & $6 \pm 1$ & $2.8 \pm 0.3$ & $17 \pm 2$ \\
\hline $\mathrm{V}-2$ & $7 \pm 1$ & $2.7 \pm 0.3$ & $15 \pm 2$ \\
\hline$V-3$ & $7 \pm 1$ & $2.8 \pm 0.3$ & $21 \pm 2$ \\
\hline$V-4$ & $8 \pm 1$ & $3.4 \pm 0.4$ & $23 \pm 2$ \\
\hline LE-1 & $10 \pm 1$ & $9.1 \pm 0.6$ & $30 \pm 2$ \\
\hline LE-2 & $12 \pm 1$ & $10.3 \pm 0.7$ & $31 \pm 2$ \\
\hline V-5 & $26 \pm 2$ & $15 \pm 1$ & $43 \pm 2$ \\
\hline TR-1 & $22 \pm 2$ & $34 \pm 2$ & $18 \pm 2$ \\
\hline TR-2 & $19 \pm 1$ & $36 \pm 2$ & $19 \pm 2$ \\
\hline 3 & $32 \pm 2$ & $6.1 \pm 0.3$ & $27 \pm 2$ \\
\hline 4 & $30 \pm 2$ & $5.2 \pm 0.3$ & $33 \pm 2$ \\
\hline 5 & $48 \pm 3$ & $6.8 \pm 0.4$ & $66 \pm 5$ \\
\hline 6 & $44 \pm 3$ & $3.9 \pm 0.3$ & $61 \pm 3$ \\
\hline 7 & $42 \pm 2$ & $3.8 \pm 0.3$ & $59 \pm 4$ \\
\hline 8 & $67 \pm 4$ & $46 \pm 4$ & $70 \pm 4$ \\
\hline PC-1 & $25 \pm 2$ & $25 \pm 2$ & $38 \pm 3$ \\
\hline $\mathrm{V}-8$ & $57 \pm 3$ & $21 \pm 2$ & $40 \pm 3$ \\
\hline V-9 & $58 \pm 5$ & $12 \pm 1$ & $36 \pm 3$ \\
\hline V-11 & $58 \pm 4$ & $10.2 \pm 0.8$ & $36 \pm 3$ \\
\hline BR-1 & $242 \pm 15$ & $18 \pm 1$ & $45 \pm 2$ \\
\hline BR-2 & $65 \pm 6$ & $13 \pm 1$ & $42 \pm 2$ \\
\hline $\mathrm{V}-12$ & $68 \pm 5$ & $38 \pm 3$ & $56 \pm 3$ \\
\hline $\mathrm{V}-13$ & $65 \pm 4$ & $33 \pm 3$ & $54 \pm 2$ \\
\hline V-14 & $84 \pm 4$ & $41 \pm 3$ & $64 \pm 3$ \\
\hline$V-15$ & $97 \pm 5$ & $44 \pm 2$ & $66 \pm 3$ \\
\hline$V-16$ & $223 \pm 22$ & $51 \pm 4$ & $68 \pm 4$ \\
\hline V-17 & $226 \pm 23$ & $61 \pm 5$ & $65 \pm 5$ \\
\hline $\mathrm{V}-18$ & $242 \pm 15$ & $43 \pm 3$ & $75 \pm 6$ \\
\hline
\end{tabular}


$\mathrm{T}$ a b 1 e 4

Inorganic antimony and selenium species in river Vardar (number of parallel determinations $n=2$ )

\begin{tabular}{ccccc}
\hline \hline Sampling site & $\begin{array}{c}\mathrm{Sb}(\mathrm{III}) \\
\mathrm{ng} / \mathrm{L}\end{array}$ & $\begin{array}{c}\mathrm{Sb}(\mathrm{V}) \\
\mathrm{ng} / \mathrm{L}\end{array}$ & $\begin{array}{c}\mathrm{Se}(\mathrm{IV}) \\
\mathrm{ng} / \mathrm{L}\end{array}$ & $\begin{array}{c}\mathrm{Se}(\mathrm{VI}) \\
\mathrm{ng} / \mathrm{L}\end{array}$ \\
\hline $\mathrm{V}-6$ & $10 \pm 1$ & $60 \pm 3$ & $11 \pm 1$ & $25 \pm 2$ \\
$\mathrm{~V}-7$ & $13 \pm 2$ & $60 \pm 2$ & $10 \pm 1$ & $27 \pm 2$ \\
$\mathrm{~V}-10$ & $12 \pm 1$ & $64 \pm 4$ & $13 \pm 1$ & $63 \pm 5$ \\
$\mathrm{CR}-1$ & $14 \pm 2$ & $55 \pm 4$ & $2.3 \pm 0.3$ & $44 \pm 4$ \\
$\mathrm{CR}-2$ & $11 \pm 1$ & $63 \pm 6$ & $5.7 \pm 0.5$ & $56 \pm 4$ \\
$\mathrm{PC}-2$ & $7 \pm 1$ & $88 \pm 6$ & $7.3 \pm 0.7$ & $34 \pm 3$ \\
\hline \hline
\end{tabular}

The higher antimony concentrations in the Greek part of Vardar $(\mathrm{V}-16, \mathrm{~V}-17$, $\mathrm{V}-18$ ) could be explained with the geological characteristics of the region $[17,18]$.

\section{CONCLUSION}

The measured concentrations of inorganic antimony, selenium and tin species were far below the allowed limits. The concentration range for total inorganic analytes was between 6 and $242 \mathrm{ng} / 1$ for $\mathrm{Sb}, 2.7$ and $61 \mathrm{ng} / \mathrm{l}$ for $\mathrm{Sn}$ and 15 and $75 \mathrm{ng} / 1$ for Se. The higher oxidation states of antimony and selenium were found as the predominant form in all studied samples. The anthropogenic influence was expressed in higher levels of antimony.

Acknowledgement. The authors gratefully acknowledge the financial support provided by Bulgarian Ministry of Education (BY X/207/2006 and "GAMA" D002-70/2008) and by the Ministry of Education and Science of the Republic of Macedonia (No. 13-3569/1).

\section{REFERENCES}

[1] Council of the European Communities. Council Directive 76/464/EEC of 4 May 1976 on pollution caused by certain dangerous substances discharged into the aquatic environment of the Community, Official Journal L 129, 18/05/1976, pp. 23-29.

[2] United States Environmental Protection Agency, Drinking Water Regulations and Health Advisories, 1992.

[3] Council of the European Union. Council Directive $98 / 83 /$ EC of 3 November 1998 on the quality of water intended for human consumption, Official Journal L 330, 05/12/1998, pp. 32-54.

[4] P. Howe, P. Watts, WHO Guidelines for Drinkingwater Quality, WHO, Geneva, 2005.

[5] Regulation for the Classification of Waters, $O f$ ficial Gazette of the Republic of Macedonia, No. 18, 31 March 1999, pp. 1165-1173.

[6] R. Iffland, in: Handbook on Toxicity of Inorganic Compounds, H. Seiler, H. Sigel, (Eds.), Marcel Dekker, New York, 1988, pp. 67-76.

[7] G. Nordberg, B. Fowler, M. Nordberg, L. Friberg, Tin in Handbook on the Toxicology of Metals, 3rd Edition, Elsevier Academic Press, Amsterdam, 2007, p. 274.

[8] J.M. Serafimovska, S. Arpadjan, T. Stafilov, Speciation of dissolved inorganic antimony in natural waters using liquid phase semi-microextraction combined with electrothermal atomic absorption spectrometry, Microchem. J. 99, 46-50 (2011).

[9] Grizo, Heavy metals in river Vardar, Ecol. Zašt. Život. Sred. 3, 43-49 (1995).

[10] E. Tserovski, S. Arpadjan, I. Karadjova, Chemical modification of volatile elements in organic solvents and extracts by dithiocarbamate and complexes of noble metals in electrothermal atomic absorption spectroscopy, Spectrochim. Acta 47B, 959-970 (1992). 
[11] M.Thompson, S.L.R. Ellison, A. Fajgelj, P. Willets, R. Wood, Harmonised guidelines for the use of recovery information in analytical measurement, IUPAC/ISO/AOAC International/EURACHEM, Technical report, 1996.

[12] L. Barandovski, M. Cekova, M.V. Frontasyeva, S.S. Pavlov, T. Stafilov, E. Steinnes, V. Urumov, Atmospheric deposition of trace element pollutants in Macedonia studied by the moss biomonitoring technique, Environ. Monit. Assess. 138, 107-118 (2008).

[13] T. Stafilov, R. Šajn, Z. Pančevski, B. Boev, M.V. Frontasyeva, L.P. Strelkova, Heavy metal contamination of surface soils around a lead and zinc smelter in the Republic of Macedonia, J. Hazard. Mater. 175, 896-914 (2010).

[14] B. Balabanova, T. Stafilov, K. Bačeva, R. Šajn, Biomonitoring of atmospheric pollution with heavy metals in the copper mine vicinity located near Radoviš, Republic of Macedonia, J. Environ. Sci. Health, Part A 45, 1504-15181 (2010).
[15] T. Stafilov, R. Šajn, B. Boev, J. Cvetković, D. Mukaetov, M. Andreevski, S. Lepitkova, Distribution of some elements in surface soil over the Kavadarci region, Republic of Macedonia, Environ. Earth Sci. 61, 1515-1530 (2010).

[16] B. Balabanova, T. Stafilov, R. Šajn, K. Bačeva, Distribution of chemical elements in attic dust as reflection of lithology and anthropogenic influence in the vicinity of copper mine and flotation, Arch. Environ. Contam. Toxicol. 61, 173-184 (2011).

[17] B. Boev, V. Bermanec, T. Serafimovski, S. Lepitkova, S. Mikulcic, M. Soufek, G. Jovanovski, T. Stafilov, M. Najdoski, Allchar mineral assemblage, Geologica Macedonica 15-16, 1-23 (2001-2002).

[18] A. Demetriades, General groundwater geochemistry of Hellas using bottled water samples, $J$. Geochem. Explor. 107, 283-298 (2010). 